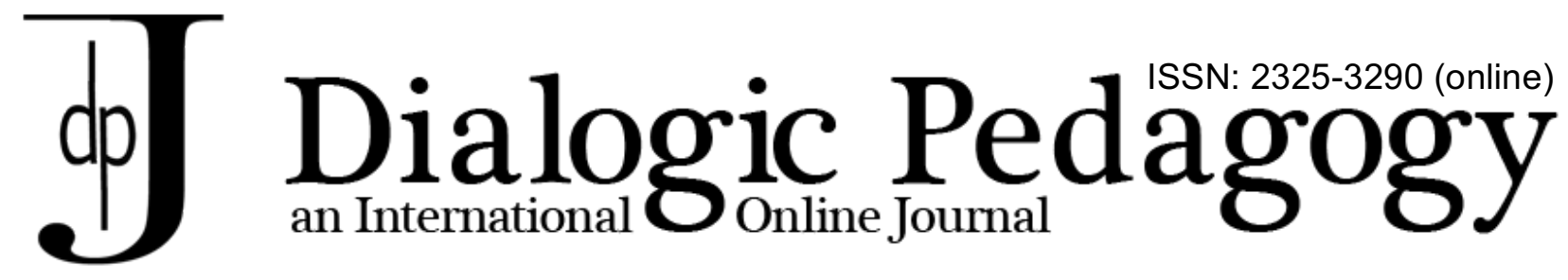

\title{
The Bakhtin of Boris Groys: Pro and Contra
}

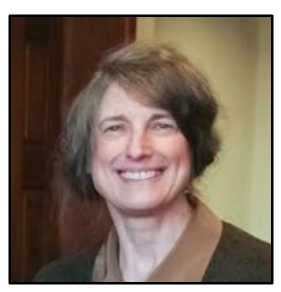

Caryl Emerson

Princeton University, Emeritus, USA

Caryl Emerson is A. Watson Armour III University Professor Emeritus of Slavic Languages and Literatures at Princeton University. Her scholarship has focused on the Russian classics (Pushkin, Tolstoy, Dostoevsky), Mikhail Bakhtin, and Russian theater and music. Current projects include the Russian modernist Sigizmund Krzhizhanovsky and the neoThomist aesthetics of Jacques Maritain.

$\cos 8080$

Mikhail Bakhtin would have loved this forum. It has everything that the most productive types of dialogue require: a strong fearless utterance with a "speaking face" behind it, emerging from a chronotopically precise but open-ended historical moment, followed by eight equally fearless responses, each coming from a different angle and each hearing the utterance against its own distinct ideological "horizon." What is more, Groys is attacking an image that Bakhtin would have found extremely unappealing, that of a canonized cult figure, an authoritative name whose signature-terms were being dropped into every academic conversation because the figure was, alas, experiencing a world-wide "boom." The fact that this image was of him would not have mattered much. As far as we can tell from the memoirs of contemporaries, Bakhtin had a playful, flexible authorial ego and almost no possessiveness about his own ideas. Naturally, he desired that his ideas circulate and stimulate others to respond, but he did not desire that his ideas become "officially" revered.

Bakhtin would welcome this forum, in short, because of his own relation to the utterance. The speaker stands behind an opinion or an interpretation, yet does not "possess it." As Michael Holquist once put the matter, for Bakhtin, meaning is not owned, only "rented"-and thus it is always in flux. Wonderful memoiristic evidence attests to the truth of this. In the early 1970s, the Dostoevsky scholar Grigorii Pomerants met several times with Bakhtin, seeking the latter's opinion on some essays he had written "of a polemical nature." Bakhtin chose not to pass judgment. Where the two men disagreed, Bakhtin remained serene and made "no attempt to defend the Bakhtin in print." On the contrary, Pomerants recalled, " . . . at times it seemed to me that he looked down on his published works 'as souls look down from on high on the body they have cast off'." In recollecting this conversation, Pomerants reflected on Bakhtin's "inner quietude," which was in such stark contrast to the agitated tone of his own polemical writing, and to the rhetoric of so much Soviet literary scholarship, both official and samizdat.

${ }^{1}$ See Grigorii Pomerants, Otkrytost' bezdna. Vstrechi s Dostoevskim [The openness of the abyss. Meetings with Dostoevsky] (Moscow: Sovetskii pisatel', 1990), 225. The chapter where this quote occurs was written in 1975, the year of Bakhtin's death. 
The feedback on Groys's "Between Stalin and Dionysus" in this forum is also agitated and polemical, but reassuringly diverse. It ranges from grateful endorsement-although perhaps not for reasons Groys would endorse - to scandalized rejection. Some contributors believe that Groys is right about Bakhtin, some believe he is wrong, and then a third overlapping group considers Groys perhaps right, perhaps wrong, but most importantly he is "useful" (that is, provocative, original, conducive to the raising of important questions). In this third group we find fascinating, unsettling case studies of dialogic pedagogy, what might be called "applied Groys." This afterword will attempt to put these responses in dialogue with one another.

Even the warmest appreciations of Groys usually introduce a caveat that refocuses or refines the argument. Consider Antonia Larrain. She finds Groys's essay "convincing and thoughtful," but would apply complex systems theory to Bakhtinian thinking in order to finesse the brutal charges of totalitarianism and totalization. Bakhtin might indeed be "political" in the ways that Groys suggests-or might lend himself to such politicization by others-but, she argues, Bakhtin's basic response to the world was aesthetic, not political. Those two responses cannot be confused. Communities are sustained by aesthetic activity. When understood as an open, unpredictable configuration of responsive encounters, a community affirms artistic totalities and thus makes political totalitarianism impossible. Groys arguably misrepresents community, which is never a homogenizing or totalizing whole. But Larrain grants Groys an important insight: that Bakhtin can confound those of us with so-called "Free World" mental habits, since he resists totalizing environments with non-liberal tools. Bakhtin is an "anti-totalitarian communist." The best resistance to Stalinism, according to Larrain's Bakhtin, is the constant production of art: continual small local acts of closure that are seen not as transcendental objects but as "provisional and partial visions" always open to re-negotiation.

Alexander Zholkovsky also welcomes Groys on Bakhtin. Over the past several decades, Zholkovsky has displayed a special gift for shrewdly debunking self-fashioned cultural icons (most vigorously, Anna Akhmatova) - and consistent with this attitude, he disapproves of Bakhtin's "Western worshippers." Bakhtin's politics aside, Zholkovsky considers the very canonization of Bakhtin to be a totalitarian act, and he is eager to deflate it. He would move Bakhtin from icon shelf back to bookshelf. Where Larrain applied a decentralizing systems theory, however, Zholkovsky is more personalistic. He pulls in, as an ally in Groys's anti-Bakhtin campaign, the great classicist and verse theorist Mikhail Gasparov (1935-2005), who for a quarter-century was Bakhtin's most high-profile, principled opponent. The juxtaposition is a good one. Both Groys and Gasparov view Bakhtin's enthusiasm for the carnivalesque as a sinister thing, not freedom-bearing but stage-managed by those in power. Zholkovsky, who cites only Gasparov's initial contra-Bakhtin publication from 1979, could have made his case more forcefully. For Gasparov went on complaining about Bakhtin until a year before his death, and his complaints became louder and less forgiving as the Bakhtin industry continued to grow and gain ever more adherents and hero-worshippers. It was not the political implications of carnival that aroused Gasparov's ire, however, as much as it was the genre of Menippean satire (which, in Gasparov's opinion, Bakhtin had simply fabricated, in his desire to rewrite not only the history of European literature but the literature itself). Gasparov also took to task Bakhtin's myth of a "dialogue" with the fictive and the dead at the convenience of the critic-which was, he claimed, nothing more than critics talking narcissistically with their own selves. ${ }^{2}$

\footnotetext{
2 For this story, see Caryl Emerson, “In Honor of Mikhail Gasparov's Quarter-Century of Not Liking Bakhtin," in Catherine O'Neil, Nicole Boudreau and Sarah Krive, eds., Poetics. Self. Place. Essays in Honor of Anna Lisa Crone (Bloomington, IN: Slavica, 2007): 26-49. For a version of this essay adjusted for a domestic Russian readership, seе Кэрил Эмерсон, «Двадцать пять лет спустя: Гаспаров о Бахтине», Вопросы литературы 2 (Март-Апрель 2006): 12-47.
} 
Also appreciative of Groys are the essays in the forum that address the theory and practice of dialogic pedagogy (Miyazaki; Lensmire and Snaza; Matusov and Marjanović-Shane). But their task, palpably experiential and concrete in actual classrooms, requires them to "think with Groys," apply his insights to living situations and see how they work, rather than merely analyze his pronouncements abstractly. Each of these essays "co-thinks" carnival wisdoms, as well as carnival clichés, in its own way. Before addressing this middle "applied" group, however, let us first pull into dialogue the other end of the spectrum, the essays that reject Groys's reading of Bakhtin pretty much out of hand. These contributions to the forum are cast in different registers and display various degrees of intolerance.

Sergeiy Sandler raises serious philosophical objections. His major methodological reservation is that Groys, by means of select quoting or misquoting, reads postmodernism back into Bakhtin from a later time. Carnivalesque and polyphonic cannot be equated. Nowhere does Bakhtin preach the death of individuality. He does not teach the death or even the absence of the author, as did Roland Barthes. Choreographed Stalinist terror, for all that the audience might laugh at the victims, is not an example of Bakhtin's carnivalesque. Carnival is an attitude, a philosophy; it is not an institution. And if a Nietzschean critique was appropriate to Bakhtin's generation, a deconstructive critique is not. ${ }^{3}$ Sandler then offers his own contextualization. Bakhtin is a personalist. The "world" of Bakhtin is always an individual's world. A collective subject is incomprehensible to him. So is the autonomous Cartesian subject. Bakhtin's hero, in carnival relations as well as polyphonic ones, is intersubjectivity. Because Groys ignores the early philosophical writings of Bakhtin, especially "Toward a philosophy of the Act” [«К фрилософии поступка»], he has misconstrued this reality. Carnival imagery is not political, Sandler insists, because it is the "world experienced individually from within," consciousness gropingly in quest of agency and the other. This cognizing body-Sandler intimates-is always experienced as misshapen, unfinished, grotesque. Sandler's thesis of a personalized carnival grotesque is the strongest freestanding philosophical utterance among the responses to Groys in this forum, deepening both Larrain's and Zholkovsky's critiques.

Of another sort altogether is Alexander Lobok's response. Lobok is angry to the point of insult and disbelief, and flies to Bakhtin's defense. It's one thing to note parallels between the crowd laughing at executions and anaesthetized carnival violence; it is quite another thing to assume that Bakhtin is therefore a source of Stalinism. In treating Bakhtin like an ideologue, Groys reveals himself as a product of the old condescending Soviet-textbook mentality toward great thinkers-Aristotle did this wrong, Kant did that wrong-whereas the necessary first step in interpretation should always be to re-create the "thinking space" of the subject. Why should Bakhtin be political at all? Lobok takes a rosy view of the task of carnival (a survival mechanism proving the "indestructibility of humanness in a human being"). More idiosyncratically, he argues on behalf of Bakhtin's "anti-totalitarian stylistics." Along the lines of Larrain and Sandler, Lobok notes Bakhtin's mode of self-expression: pulling the reader in, loosening up the authoritative claims of the text, and celebrating other authors who do the same. These traits of writing are inevitably personalizing and thus anti-totalitarian. One must attend to the effect of the voice in the texts, not only to the facile chimera of Bakhtin's outward images.

3 In "deconstructing" Bakhtin from a later time, Groys is in distinguished company. In the forum "The Contexts of Bakhtin" published in the premiere post-Soviet humanities journal Novoe literaturnoe obozrenie in 2006, two postmodernist émigré critics, Mark Lipovetsky and Irina Sandomirskaia, interpreted Bakhtin as suspicous toward the image and cynical toward the word. See Mark Lipovetskii and Irina Sandomirskaia. "Как не завершить Бахтина? Переписка с двух электронных углов" [How is one not to 'finalize' Bakhtin? A Correspondence from two electronic corners]. Novoe literaturnoe obozrenie 79 (2006): 7-38. Craig Brandist and Evgeny Dobrenko mount the most sustained criticism of Lipovetsky's and Sandomirskaia's appropriating dialogic approach, insisting that Bakhtin's intellectual sources in German philosophy, as well as the concrete conditions of his Soviet life, be considered primary in keeping Bakhtin "unfinalized." 
The remaining responses to Groys attempt to apply Bakhtin in a productive rather than an accusatory way, from within Bakhtin's own "thinking space." In a retrospective that is startlingly relevant today, Marek Tesar points out parallels between Bakhtin and Vaclav Havel's post-totalitarian treatise, The Power of the Powerless (1985). Kiyotaka Miyazaki takes exception to Groys's assumption that polyphony (and to a certain extent carnival) must have a "super-author," a Stalin figure, masterminding the whole. At best those outside figures "organize" their human material; they do not control its potentials. Here Miyazaki asks us to follow him into the dialogic classroom. This will become the site for the final two essays, the most "professionally invested" in the Bakhtinian subfield of dialogic pedagogy.

Lensmire and Snaza are harsh on Groys-but unlike Lobok, good-naturedly so, offering correctives rather than condemnations. Groys (and Zholkovsky too) want to decrown Bakhtin, to prove he is not a saint. But who ever said he is a saint? It is certainly not Bakhtin's fault that a boom and a cult rose up around him. Blame his disciples, blame the readership if you must, but not the man himself. (Even Mikhail Gasparov admitted that the influence of Bakhtin among apprentice scholars and the trend-setting young was the problem, more so than Bakhtin's own strange, poignant individual trajectory.) Lensmire and Snaza take a close and critical look at the primary reader of Bakhtin in this forum, Boris Groys himself, a person (they suggest) who comes across as "elitist," official, frightened by the "stinking folk." Because of his own anxieties, Groys imposes binaries on Bakhtin and passes judgment on his politicswhereas a more productive route would be to examine Bakhtin on the concept of "the political." Here we confront a radiant, messy, porous and participatory scenario, inflected by an open-ended Hegelianism but not at all totalizing: "What is, has become, and this implies, of necessity, that it can become otherwise."

Matusov and Marjanović-Shane provide the forum's most open-ended, ambivalent, and risk-laden testimonies. They see both inspiration and considerable danger in "applied dialogics." Bakhtin's "mystical organic cosmic holism" does not impose a politics, it is humble about what it knows. There is much in this organic holism that is relevant to a polyphonic education, rooted as it is in "internally persuasive deconstructive discourse." But the school is an institution (and a graduate school is a certifying institution), not a cosmos and not a carnival square. A power hierarchy is both built into it and presumed by its participants. This hierarchy can be masked or softened, but if dissolved altogether there is no reason to go to school; more interesting and fun would be to kick your teacher in the belly or shout her down with public-square billingsgate. And that would be a waste of everyone's time.

What I found most instructive in this essay were the embedded case histories. The first is the account of Lensmire's pedagogical experiments with a dialogic (that is, with a Rousseauean or Tolstoyan) classroom of third-graders; the second is Matusov's trial experiments in dialogizing his graduate seminars. The former revealed that Bakhtin (in keeping with his utopian sociology of carnival) does not take seriously the fact of "horizontal oppression," that is, the powerful impulse of children to beat up on their peers. This is a bullying that can be kept in check by a modest amount of vertical authority from the teacher. And Matusov's experiment with his older students was an eye-opener. Pulling adults-in-training into free dialogue, asking them to identify their private concerns with their classroom selves and make both public, leaving it up to them to "complete whatever assignments they want," can be not liberating but invasive-and enslaving. For a polyphonic teacher is not comparable to a polyphonic novelist, or only very naïvely so. Can you "question someone to despair or death?" asks one of Matusov's students. Matusov calls such questions an expression of "epistemological pain," and wonders if salaried teachers, even with the best intentions, have the right to inflict it. He would like teachers to stand behind "students' power" (meaning: students' responsibility for their own intellectual growth) and admits, along with Groys, that Bakhtin offers only partial support in this task. Bakhtin's mystic holism and his distrust of liberal institutions-his disinterest in the details of governance-present a huge challenge to dialogic pedagogy, 
which is obliged to work within institutions and not with people at their free and festive leisure. These are all familiar anxieties raised against Bakhtinian carnival when it is presumed to be a politics, a revolution, an end rather than what it actually is, which is an attitude. The solution, perhaps, is for teachers to withdraw sooner rather than later from their students. This would "respect their final authority." But the student still desires the grade, the accolade, the glowing letter of recommendation, the academic degree. Can those goods be provided in the absence of respect for the vertical hierarchy?

In closing, several thoughts. Groys is not alone, of course, in distrusting Bakhtin's carnival, his celebration of cultures of laughter and his delight at the bodily grotesque. Alexei Losev and Sergei Averintsev had deep reservations of a religious nature. Viktor Shklovsky worried about the timeless, ecstatic nature of Bakhtin's carnivalized menippea. A decade after Boris Groys emigrated from the USSR to Germany, Mikhail Ryklin, of the "Laboratory of Post-Classic Studies" within the Soviet Academy of Sciences in Moscow, authored his "Bodies of Terror" [Tela terrora] (1990). Alongside Groys, Ryklin was determined to decrown and demystify carnival. Ryklin too identified the book on Rabelais as a "hymn to the victory of the collective," whose major trope was "individuation as a sin par excellence." Under the influence of the French postmodernist Jean Baudrillard's work on the seductiveness of simulation, Ryklin analyzed the stultifying "pan-speech" of collective Soviet subjects, fearfully present in the iconography of the Stalinist Moscow Metro. ${ }^{4}$ All these theorists and critics would find Groys a provocative ally, even if they stopped short of assigning Bakhtin to the category of "crypto-Stalinist" and Bakhtin's writings on polyphony and carnival to the "mindset of the 1930s." Groys's essay was a product of its liminal time, a historical document, and even its overstatement would have made Bakhtin smile.

But there is a final, more narrowly pedagogical reason why Bakhtin would have welcomed this forum, and especially its appearance in the pages of Dialogic Pedagogy. The first full-time job that Bakhtin held was at the Saransk Pedagogical Institute; he was a professional teacher of teachers. During the final years of World War II (1944-45), Bakhtin supported himself and his wife by teaching German and Russian to high school students in Kimry on the Volga River, east of Tver. Volume 5 of Bakhtin's Collected Works contains an essay that Bakhtin prepared for publication in 1945, "Questions of Stylistics in Russian Language Lessons in Secondary School." ${ }^{5}$ In this essay Bakhtin describes how the Russian masters-Gogol and Pushkin-worked creatively with syntactical constructions and the conditional mode to make causality problematic and to "open up" interpretive potentials in their texts. ${ }^{6}$ In the belly of the Stalinist beast, armed with nothing more subversive than grammatical categories, Bakhtin was teaching Russian literature through a type of dialogic stylistics that recalls the "anti-totalitarian stylistics" Alexander Lobok identifies in Bakhtin and praises in this forum. Bakhtin practiced such a stylistics not only in his carnivalistic attitude toward his own survival, but also in the traditional and censored Soviet classroom. If, as Grigory Pomerants claimed, Bakhtin looked down with bemusement on his own published texts as if on "bodies bereft of a soul," then that soul was relocated in readers, students, receivers, the other half of the communication arc. How could Bakhtin fail to appreciate all the potentials that this forum has unleashed?

\footnotetext{
${ }^{4}$ Ryklin's "Tela terrora" first appeared in Bakhtinskii sbornik I (Moscow, 1990): 60-76. A translation into English as "Bodies of Terror: Theses Toward a Logic of Violence," by Molly Wesling and Donald Wesling was published in New Literary History, vol. 24.1 (Winter 1993): 45-49.

5 «Вопросы стилистки на уроках русского языка в средней школе», М. М. Бахтин, Собрание сочинений т. 5 (Москва, Русские словари, 1996): 151-56. The essay was first published in 1994.

${ }^{6}$ To my knowledge the first integrative discussion of this pedagogical essay in English is by Irina Sandomirskaia, "Bakhtin in Bits and Pieces: Poetic Scholarship, Exilic Theory, and a Close Reading of the Disaster," in the forum "The Dark and Radiant Bakhtin. Wartime Notes," edited by Irina Denischenko and Alexander Spektor, Slavic and East European Journal, vol. 61.2 (2017): 278-98, esp. 282-87.
} 


\section{(c) $)$ EY}

New articles in this journal are licensed under a Creative Commons Attribution 4.0 United States License.

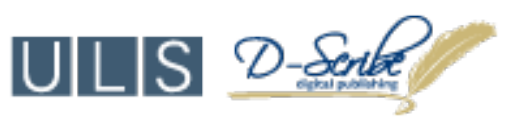

This journal is published by the University Library System, University of Pittsburgh as part of its D-Scribe Digital Publishing Program and is cosponsored by the University of Pittsburgh Press. 